\title{
Ships on Hero Stones from the West Coast of India
}

\author{
Sila Tripati \\ Marine Archaeology Centre \\ National Institute of Oceanography \\ Dona Paula, Goa 403004 (India) \\ Email: sila@nio.org
}

\begin{abstract}
Hero stones were raised to honour the memory of those who lost their lives either in a battle (sea or land) or in some other untoward accident. This practice has been continued since the early times and varieties of hero stones have been reported from various provinces of India. Maximum number of hero stones so far reported from India has been depicted with land battle scenes and other societal aspects, where as the hero stones kept at Archaeological Museum, Old Goa, Goa (12th century $A D$ ) and Eksar (11th century AD) in Mumbai have the depiction of naval warfare. The Old Goa hero stones belong to the Goa Kadambas who ruled Goa from 950-1300 AD. The Eksar hero stones were depicted during the reign of king Bhoja of Malwa in 1020 AD. Similar type of hero stones with depiction of boat motifs datable to the 18th to 19th centuries AD has been reported from Aramda in Gujarat. This paper examines the hero stones depicting naval warfare of India and their significance along with the naval battles and maritime history of India.
\end{abstract}

\section{Keywords}

Naval Warfare, Hero Stones, Memorial stones, West Coast of India, Old Goa, Eksar, Aramda 


\section{Introduction}

The Indus valley (3500 BC) people were the first mariners of India who had trade relations with Mesopotamia, Oman, Bahrain and Makran coast and the geographical position affords her a natural advantage for attaining the maritime dominance. The ports on the east and west coast of India played a significant role in disseminating Indian culture on the overseas countries. The ports of India were under the dominion of several dynasties. Different ports were prominence in different periods of history. With passage of times ports were declined or deserted due to untoward attitude of the rulers and some were due to natural factors such as coastal erosion, sedimentation and sea level changes. In spite of all the problems the maritime traders and trade was never stopped. The archaeological, numismatic, literary, epigraphic, travellers account, art evidence etc provide ample information on the maritime, shipping, trade and cultural contacts of India with other countries from the Protohistoric period onwards. But these sources hardly mention about the risks such as the losses of lives, pirate menace, safety and shelter to the survivors of wrecked vessel, accidents and other navigational hazards during the sea voyages. However, limited sources throw light on the dangers faced by the mariners. The Sanskrit and Pali literature contains innumerable allusions to vessels wrecked on the high seas. The adventurous mariners tossed their cargo in the waves of the sea in times of danger and promised their Gods to make a donation if ever He brought them safely out of this peril. The Buddhist goddess 'Tara' is the protectress and a number of 'Tara' images have been found in the excavations at Ratnagiri in coastal Orissa showing a sinking boat and the boatman invoke help of 'Tara' for rescue from sinking (Mitra, 1983). To get rid of the piracy problem emperor Asoka (273- 232 BC) had issued a copper plate edict known as Marine Edict for the Naga rulers, which was however contemptuously set at naught by those for whom it was meant (Mookerji, 1912). The Motupalli pillar inscription of Ganapatideva 1244-45 AD of the Kakatiya dynasty of coastal Andhra Pradesh assures the safety to traders (Abhaya Sasana) arriving from all continents risking the sea voyages and its hazards like storm attacks and shipwrecks (Hultzsch, 
1913-14). In spite of all kind of hazards the sailors continued maritime trade throughout the ages.

The study of hero stones depicting naval warfare not only helps in reconstructing the maritime activity of India but it would accord well deserved exposure to the people involved in the maritime activities. The present paper deals with the hero stones of India in which scenes of naval warfare have been depicted and those have been discussed. Evidence of naval warfare and history of hero stones in India gleaned from various sources have been highlighted. There are very few attempts to chronicle this aspect.

\section{Evidence of Naval Warfare in India}

Boats were not only engaged for transportation of cargo, crossing rivers and lakes pleasure trips for noble people but also for naval warfare. This practice also appears to be very old. The art of employing boats and ships for military purposes was known in India since the Early Historical Period. However, the Rig Veda refers to naval warfare and states that Bhujyu the son of Rishi king Tugra was sent for naval warfare to distant islands to fight against the enemies, however his ship wrecked by a storm in the mid sea was rescued by the two Asvins (Bag, 1988). The Arthasastra (3rd century BC) of Kautilya mentions Navadhyaksha or the Superintending of boats and ships, engaged in trade activities and collecting taxes from the ships sailing in the sea and those moving in the rivers. The text further mentions the word that Himsrikah, which means pirate ships and the Navadhyaksha had to see that they were pursued and destroyed whenever they were found (Shamasastri, 1967). Similarly the same regulation was applied for the vessels of the enemy countries when they were sighted in territorial waters. It is known from the Vayalur inscriptions near Mahabalipuram that the Pallava king Narasimhava Varman - II (680-720 AD) had naval wars and conquered Lakshadweep Islands with the help of his fleet of ships. The inscription reads: 
May he exercise the royal prerogative and take up the vow of administering (his) subjects up to the extremities of his kingdoms, as even to include the Dvipalaksham (thousand of islands).

The inscriptions of King Harsha Vardhana (606-647 AD) of Kanauj refer that his victorious camp was furnished with ships, elephants, and horses: mahanauhastya-sva-jaya-skandhavarai. Similarly, the Aihole inscription of Pulakesin II (610-642 AD) of the Chalukya dynasty states that Pulakesin II attacked Puri (probably Elephanta Island, near Mumbai) with his fleet of hundred fighting vessels, defeated the Mauryas, annexed the North Konkan to his empire and reduced Puri to submission (Chaudhari, 1982). During the reign of Kumarapala there were rebellions and insurrections throughout the kingdom, Vaidyadeva, the minister restored peace in the whole empire with the help of strong navy. This shows that the royal navy under the Palas (8th to 11th century $A D$ ) was efficient both for offensive and defensive purposes. The Cholas were also a great sea power. It was under the Cholas the naval power of the Tamil land attained its culminating point. The Chola kings appear to have organised a fleet of ships, which enabled their troops to cross over the ocean and invade the neighbouring islands. Rajaraja Chola (984-1013 AD) destroyed the fleet of the Chera and also conquered Ceylon. The overseas conquests of Rajendra Chola (1013-44 AD) have been recorded in many of inscriptions. The inscriptions found on the Rajarajesvara temple at Thanjavur states that "he despatched many ships in the midst of the rolling sea" and it is said to have invaded up to the Ganges and conquered, Gujarat, Nicobar Islands, Malay Peninsula, Sumatra, Lakshadweep and Maldives. This was the climax of the Chola naval achievement (Mookerji, 1912). The Tilakamanjari (8th century AD) of Dhanapala narrates in great detail the victorious expedition of Samaraketu to Indonesia (Chandra, 1977). On the other hand, the Rashtrakutas (8th to 10th century $A D$ ) had maintained fleet in the West Coast of India. Originally the Goa Kadambas hailed from Banavasi (presently in Karnataka) and they ruled over Goa from 950-1300 AD (Fig. 1). The power of the Kadambas reached its zenith under the king Jayakeshi (Gune, 1979). Some inscriptions issued by the rulers of the Kadamba dynasty refer to 
sea voyage and naval activities. For instance, the inscription of Narendra describes that king Jayakesi (1104-1148 AD) built a bridge with line of ships reaching as far as Lanka and conquered Lanka and Kavadidvipa, probably Kavaratti Island of Lakshadweep (Barnett, 1982). The inscription reads: Chattayyadevam devaraja prakatita vibhavam Svikritaschayya saurayyam Kavadi dvipamum adiage palavum dvipamgalam kondu.... This shows that rulers of the Kadamba dynasty had maintained an efficient navy. Besides inscriptions, the literary sources also mention the construction of ships meant for naval warfare. The Yuktikalpataru (the wishing tree of artifice) composed by the king of Bhoja of Dhara (11th century AD) gives a detailed account of boats and ships and the class of boats according to the length and position of the cabins. The Yuktikalpataru specifies the ships, which use to have the cabin towards prows called agarmandira. These types of boats used for long voyages and equally suitable for naval warfare. The text mentions: Cheera prabhasayatrayan rane kale ghanatvaye (Chaudhary, 1976).

\section{History of Hero stones and Memorial Stones in India}

Hero stones are erected for commemoration with basic concept to raise in memory or honour of the dead who lost their lives in a violent contest. However hero stones do not form part of the actual practice of the disposal of the dead. These upright slabs of stone, which are mostly free standing, have horizontal bands of sculpture on their surface. These stones are known in various terms such as viragals, natukals, nadukkals, paliyas, govardhan stambhas, kirti stambhas and chhaya stambhas widely distributed in India. Most of them represent land fights in which relief of horses and elephants, camels were depicted along with the hero. The practice of erecting hero stones in India is very old. The Vedic texts refer to the erection of a monument for the memory of the dead person. The practice of erection of tumulus or mound with an attached post is referred in the Satapatha Brahamana. Further, the Satapatha Brahamana (9th8th century $\mathrm{BC}$ ) describes in detail (selection of site, direction, location and procedure) of the erection of the monument. These are related to funeral practices. During the days of King Asoka (3rd century BC) hero stones were 
erected on wooden posts and subsequently stone as a more durable material probably replaced wood (Patil, 1982). The Asokan monolithic pillar was in the nature of a memorial but associated with the personality and preaching of Buddha and the Buddhism. The origin of memorial stones of the later periods originates from here. The association of funeral practices with the erection of memorial stone continued for long time and is still practiced today. But this is not the case with all hero stones and during the later period only hero stones were erected without the ashes or charred bones of the dead person. Memorial stones contain funeral remains, where as hero stones are only related to the death of a person who died in a battle, war or similar kind of activities without any funeral remains. The bands of sculptures on the hero stones not only provide artistic attainment, but also the social and cultural history of the region of that particular period. The folklore and ballads of India is full of heroic acts. Hero stones are known in different terms in different parts of India and have been reported from Gujarat, Maharashtra, Goa, Karnataka, Kerala, Tamil Nadu, Andhra Pradesh, Rajasthan, Himachal Pradesh and Central India (Settar \& Sontheimer, 1982). These stones mainly dealt with either land fights or for some other societal purposes like sati (self immolation) where as hero stones depicting naval battles have come to lime light only from Archaeological Museum, Old Goa and Eksar in Mumbai (Fig. 2). Extensive research on hero stones has not been carried out in India. Although memorial stones exists in many parts of India but the Saurashtra region of Gujarat seems contain more in number because of frequent internal and external wars (Doshi, 1982). The Sangam Period (3rd century BC to 3rd century AD) literature such as Ahananuru and Purananuru refers to the hero stones (Nagaswamy, 1974). In the peninsular India Karnataka (930) has more hero stones followed by Andhra Pradesh (476), Kerala and Tamil Nadu (317). In recent years innumerable hero stones have been discovered in Tamil Nadu (Rajan, 2000). The earliest chhaya stambhas of India is reported from Andhau in the district of Kutch, Gujarat datable to the 1st century $A D$, which is the memorial of a Ksatrapa king (Ghosh, 1989). In fact memorial stones of south India datable to the 3rd century AD are found in Nagarjunakonda in Andhra Pradesh in which 
names of the warriors are mentioned and are carved elaborately (Patil, 1982). There used to be folk variation and regional variation in erecting the hero stones and the geographical distribution of the hero stones is also significant.

\section{Hero stones of Archaeological Museum, Old Goa}

A number of hero stones have been exhibited in the Archaeological Museum, Old Goa (Rajagopalan, 1987). Out of them four hero stones have the ship depictions. Three of them are carved with naval battles which probably took place in the 12th century AD during the time of Goa Kadambas who launched a series of attacks on North Konkan; the fourth one, also depicting naval battle is datable to the 15th century AD.

In the lower panel of the first hero stone a double-ended vessel, with a longitudinal curve of the hull and carrying soldiers armed with bows, spears and shields has been depicted. The middle panel depicts the hero taken to heaven by two women: Siva Linga is shown in the upper panel and the Moon is depicted above the Linga (Fig. 3). In the second (Fig. 4) longer canoe-shaped craft is shown, which is fitted with an axial rudder and propelled by 7 rowers facing backwards. Oar ports are just below the gunwale line; amidships there is a fighting platform soldiers shown with bows and at the stern, the rails of a gallery. The third one (Fig. 5) is seen on rollers, where a fight is going on in which a soldier is struck by a footman's dagger. Masts are not seen. This vessel looks broad in proportion to its length, with probably a sharp stern. The gunwale line is not continuous. There are four oars and the ornamentation on the vessel can be seen clearly. The most noteworthy feature is the sternpost rudder hung perhaps lashed by rope. Railings are fitted for the helmsman. The last hero stone depicts craft of the same type, crowded with troops armed with bows is datable to the 15th century $A D$ (Fig. 6). They are formed of planks sewn together, square openings for the oars below the gunwale, a stern gallery and an axial rudder. The costume and coiffure of the warrior, similar to the ones we find in the Hoysalesvara temple at Helebidu, Karnataka suggest that this carving dates from the middle of the 12th century AD. In the Archaeological Museum, Old Goa two 
kinds of ships are represented. The first two hero stones depict vessels whose stem and stern are curved as seen in dugouts and resemble double-ended canoe-shaped fishing boats plying along the Konkan coast. Some of the ships represented in the Goa Museum, on the contrary, depict long horizontal thick strips laid over the plank edges evidently, wadding of coir, which presses on the joints and prevents leakage.

\section{Hero stones of Eksar}

There are six hero stones having varied panels and different sizes datable to 11th century $A D$ in Eksar village near Borivali in Mumbai. In the first two hero stones some land battle scenes have been portrayed, where as the rest four hero stones have the scenes of naval battle. The third hero stone has four panels. The first panel shows five ships with number of oars and single mast on each ship and these ships are ready for battle (Fig. 7), the second panel shows four ships attacking a big ship and casualties are shown on the ship and in the sea. There is an inscription in this panel, which cannot be deciphered at all due to its illegibility. The third and fourth panel represents the worshipping of the Siva Linga and presentation of Siva and Parvati.

The fourth hero stone has eight panels. The first panel shows eleven ships equipped with soldiers and weapons for naval battle. The second panel represents with five ships attacking a boat coming from the right; the third panel has nine ships returning after victory. In the fourth panel soldiers are seen disembarking from the ship. Army is shown in the fifth panels who are marching with distinguished persons. The other panels deal with worship of Siva Linga.

The fifth hero stone has four panels. In the first panel there are seven ships with masts and oars (Fig. 8), and king is shown seated under a canopy in the ship. The second panel has six ships and three each are proceeding from left and right to engage in a naval battle (Fig. 9). The rest two panels portray worship of Siva Linga, and scenes of music and dancing. The sixth hero stone has two panels. In the bottom panel, ships are shown engaged in naval battle and in the top panel a warrior in shown seated. 
Some hero stones of Eksar have inscriptions, but due to illegibility the inscriptions cannot be deciphered. If these inscriptions could have been deciphered than it would have been possible to know who were the real participants in this naval battle and their exact date. These hero stones are important both in terms of history of the region and the kind of crafts used in the naval battle. The Bansawada Copper plate of Bhoja Deva mentions that king Bhoja Deva gave land in charity after his victory over the Konkan (Bhandarkar, 1912). Further the copper plate of Betma near Indore (Vikrama Samvat $1076=$ 1020 AD) states that king Bhoja of Malwa celebrated his victory over Konkan and donated a village to a Brahman who belonged to Napad in Kaira village (Diskalkar, 1925-26). Other scholars believe that these stones were probably set up during the time of the Silahara dynasty of the northern Konkan to commemorate naval fight in the 12th or 13th century AD (Chandra, 1977).

\section{Description of boats depicted on Hero stones of Eksar}

The boats show planked craft, sharp ended, with a long projecting bow strongly raked. Oars are positioned at a single level, which passes through holes cut below the gunwale along each side and blades are not seen. Rows of oarsmen are sitting and facing backward. The steering gear is not seen. In between the two lines of rowers, probably there is a raised platform on which the warriors fight. All the ships carry one mast held firm in the deck. It is also not easy to determine the size of these vessels. All the ships have projecting sharp prows and stout masts with cords. The sails have been folded as is done when ships are in action. Each ship has one mast and a number of oars. These ships were decked. The seating arrangements for the paddlemen below the gunwale protect them from enemy attack and further allow free movement of the soldiers (Apte, 1973). The oared vessels carved in Eksar hero stones look similar to the traditional type of crafts such as macava, batela and padava of Maharashtra coast of India. The ships depicted at Eksar do not have any horizontal lines, which may represent planking. These round hulled could have been built according to the Indian tradition of rebetting technique, which is known in Gujarati 
as vadhera (Hornell, 1930). In this method the Z-shaped edges of the planks are grooved in such a way as to enable them to hold together securely.

The significance of these representations of warships is quite clear and those are closely intertwined with the boatbuilding tradition of the West Coast of India. The present day planked vessels of the region and the ships represented in the memorial stones have close resemblance in their construction patterns.

\section{Hero stones of Aramda and Positra}

Sailors and seamen of various communities like Kharva, Bhadela, Miana, and Vagher inhabit the coastal region of Kutch and Saurashtra of Gujarat, west coast of India. Family members of these communities raise hero stones in their memory who died in the sea. Sometimes ship with a sailor or sailors are depicted in those hero stones (Fig. 10). Often a portrait of a horse rider is shown in place of ship and sailor for events in the recent past. During the recent marine archaeological explorations a number of hero stones were noticed in Aramda village and three of them have boat motifs. Out of them two hero stones have inscriptions and most portions of inscriptions are damaged and defaced (Fig. 11). The earliest date of one hero stone is (Vikrama Samvat $1852=1796$ AD) and attempts were made to decipher the inscription which reads: Samvat 2005 Pausa da 13 Somabara Thakarsi Trikamba swarga..... (On Monday 13th day of the month of Pausa of the Indian calendar (December-January) Shri Thakarsi Trikamba passed away to the heaven). The other lines of the hero stone are illegible. Similarly the inscription on other hero stone is illegible. These hero stones were dedicated to Kharva communities. One of them is more than 200 years old. The boat has several sails and appears like a sea going vessel. One of the hero stones has boat motif. Local information suggests that this hero stone was erected in the memory of seven persons who died due to capsizing of boat. These boat motifs indicate the importance of those persons who were involved in the maritime trade of this region and engaged in long sea voyages. 


\section{Discussion and Conclusions}

Generally hero stones are divided into three vertical panels. The lowest panel represent the scene of the fight, the middle panel depicts the hero is taken to heaven. The god represented in the top panel is usually a Siva Linga. Some times the Sun and the Moon are also shown. According to the tradition of great divine trinity, Brahma was the lord of Creation, Vishnu of Sustenance and Siva of Destruction. The depiction of Siva or Kailasa as the last resort of the hero testifies to the fact that those who were responsible for the hero stones accepted this classical theory.

In India the representation of boats and ships on the temple walls, paintings, coins, seal and sealing and pottery show the evidence of maritime activity of India and inscriptions refers to the naval warfare of different periods. Hero stones carved with the scenes of naval warfare have been reported only from Goa and Maharashtra datable to the medieval period. Probably, the extensive survey in this direction would bring similar kind of more hero stones. Further naval warfare hero stones have not been reported from the East Coast of India. The maritime history and the practice of naval warfare in India are very old; however no evidence hero stones depicting naval battles belonging to the ancient period have come to lime light. The question arises why more number of naval warfare hero stones are not found in India. The reason could be that courtiers inscribe achievements of only the victorious kings. It appears that the hero stones were confined only among the warriors and soldiers who fought the war or battle, when they die it was the job of the family or the community to erect the hero stone. Probably due to this reason not many naval warfare hero stone are found.

The number of naval battles fought along the Goa and Maharashtra coast, which is comparatively more than other coasts of India; hence naval warfare hero stones are plenty. Except Tamil Nadu, no evidence of naval warfare is available on the east coast of India. Gujarat is the earliest maritime state of India and still the maritime community of Gujarat undertake the maritime trade with others parts of the world. 
The hero stones found at Aramda and Positra either belong to the sailors, traders or pirates. More details on these hero stones cannot be described, as the inscriptions are illegible. These hero stones indicate that the tradition continued till to the later period and confined with some communities of Gujarat.

The boats depicted on the hero stones show the type of vessels used in naval warfare and maritime trade and the people to whom the hero stones dedicated were the warriors and sailors. The vessels depicted on hero stones of Old Goa appear like dugouts and canoes, which are still used by local fishermen. The vessels on hero stones of Eksar resemble with traditional crafts such as macava and padava, which are in use along the coast of Maharashtra. However, the vessels of Eksar are bigger and larger than that of Old Goa. These vessels are indigenous origin and people have been using since long period. Local sculptors might have carved these depictions. No external influences on carving of the hero stones and boat motives have been noticed on these hero stones. The systematic research on the hero stones can provide further in depth knowledge on the maritime activities of India.

\section{Acknowledgement}

The author is grateful to Director NIO and Shri K. H. Vora Scientist-in-Charge for their guidance. Thanks are also due to my colleagues at Marine Archaeology Centre, the Archaeological Survey of India for providing the photographs, to Shri S. B. Chitari for preparing the drawings and to Shri Skeikh Ali and Shri Umesh Shirsat for the photographs. NIO's contribution No: 3981. 


\section{References}

Apte, B. K., 1973, A History of the Maratha Navy and Merchant ships. State Board for Literature and Culture, Government of Maharashtra, Bombay.

Bag, A. K., 1988, Ships and shipbuilding technology in ancient and medieval India. In S. R. Rao (Ed.), Marine Archaeology of Indian Ocean Countries, 8-11. National Institute of Oceanography, Goa.

Barnett, L. D., 1982, Inscriptions at Narendra. Epigraphia Indica, 13: 298-326.

Bhandarkar, D. R. 1912, The Banswara Plates of Bhojadeva (Vikrama) Samvat 1076. The Indian Antiquary, 41: 201-202).

Chandra, M., 1977, Trade and Trade Routes in Ancient India. Abhinav Publications, New Delhi.

Chaudhari, K. K., (Ed.), 1982, Maharashtra State Gazetteers Thane District. Gazetteers Department, Government of Maharashtra, Bombay.

Chaudhary, M., 1976, Shipbuilding in the Yuktikalpataru and Samaranganasutradhara. Indian Journal of History of Science, 11. 2: 137-147.

Diskalkar, D. B., 1925-26, Betma Plates of Bhoja Deva. Epigraphia Indica, 18: 320-325.

Doshi, S., 1982, Paliyas of Saurashtra. In S. Settar, and G. D. Sontheimer (Eds.), Memorial Stones: a study of their origin, significance and variety, 157-173. Institute of Indian Art History, Karnatak University, Dharwad and South Asia Institute, New Delhi.

Ghosh, A., (Ed.), 1989, An Encyclopaedia of Indian Archaeology, 1. Munshiram Manoharlal, New Delhi.

Gune, V. T., (Ed.), 1979, Gazetteer of the Union Territory of Goa, Daman and Diu. Part-1, Gazetteer Department, Government of Goa, Panaji.

Hornell, J., 1930, The Tongue and Groove Seam of the Gujarati Boatbuilders. Mariner's Mirror, 16: 310-312.

Hultzsch, E., 1913-14, Motupalli Pillar Inscription of Ganapatideva, AD 1244-45. Epigraphia Indica, 12: 188-197.

Mitra, D., 1983, Ratnagiri (1958-61), 2. Memoirs of Archaeological Survey of India No. 80. New Delhi. 
Mookerji, R., 1912, A History of Indian Shipping, Longmans, Green and Co, Bombay.

Nagaswamy, R., (Ed.), 1974, Seminar on Hero stones Tamil Nadu. State Archaeology Department of Tamil Nadu, Madras.

Patil, D. R., 1982, The origin of memorial stones. In S. Settar, and G. D. Sontheimer (Eds.), Memorial Stones: a study of their origin, significance and variety, 47-58. Institute of Indian Art History, Karnatak University, Dharwad and South Asia Institute, New Delhi.

Rajagopalan, S., 1987, Old Goa. Archaeological Survey of India, New Delhi.

Rajan, K., 2000, South Indian Memorial Stones. Manoo Pathippakam, Thanjavur. Ray, H., 1936, The Dynastic History of Northern India, Vol. II, Calcullta.

Sastri, H. K., 1925-26, The Vayalur inscriptions of Rajasimha II. Epigraphia Indica 18: 145-52.

Settar, S. and Sontheimer, G. D., (Eds.), 1982, Memorial Stones: a study of their origin, significance and variety, Institute of Indian Art History, Karnatak University, Dharwad and South Asia Institute, New Delhi.

Shamasastri, R., 1967, Kautilya's Arthasastra. Mysore Printing Prees and Publishing House, Mysore. 


\section{List of Figures}

1. Figure showing the geographical domain of the dynasties discussed in the text with their dates.

2. Figure showing the locations from where hero stones reported and other sites referred in the text.

3. Double ended vessels carrying soldiers and other panels depicting scenes of heaven, Siva Linga and Moon, Old Goa Museum. Photo: Archaeological Survey of India.

4. A canoe shaped naval ship along with soldiers carrying bows, Old Goa Museum. Photo: Archaeological Survey of India.

5. Naval ship seen on roller, soldier holding spear, and fighting is going on, Old Goa Museum. Photo: Archaeological Survey of India.

6. Naval ship carrying soldiers armed with bows, Old Goa Museum. Photo: Archaeological Survey of India.

7. Ships shown with soldiers, oar and single mast on each ship ready for battle, Eksar. Photo: Archaeological Survey of India.

8. Seven ships shown oars, single mast, and soldiers, Eksar. Photo: Archaeological Survey of India.

9. Ships proceeding from both sides for naval battle, Eksar. Photo: Archaeological Survey of India.

10. Hero stone shown with ship and sailors, (after Jain 1982).

11. Two hero stones engraved with boat motifs and inscriptions, Aramda. Photo: National Institute of Oceanography. 

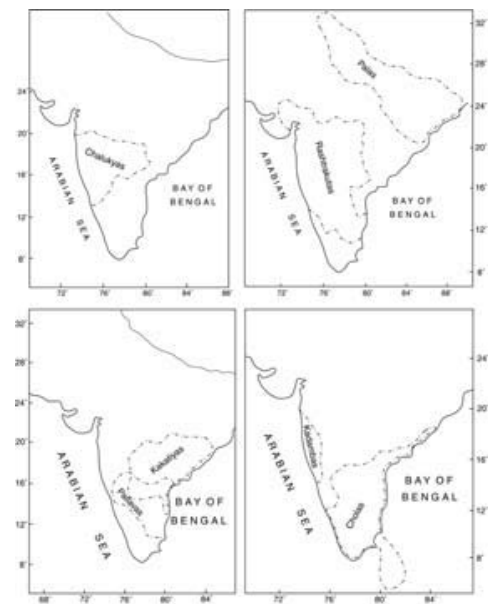

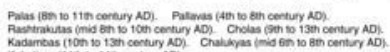

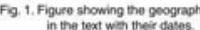

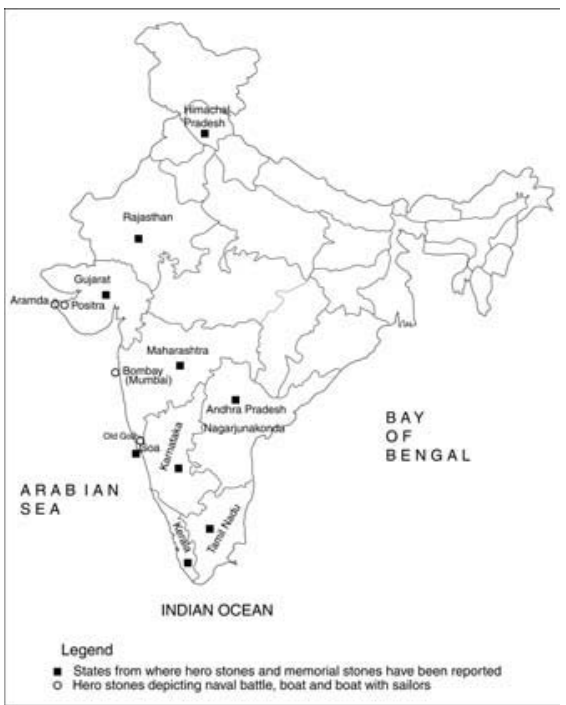

Fig. 2. Figure showing the locations from where hero stones reported and

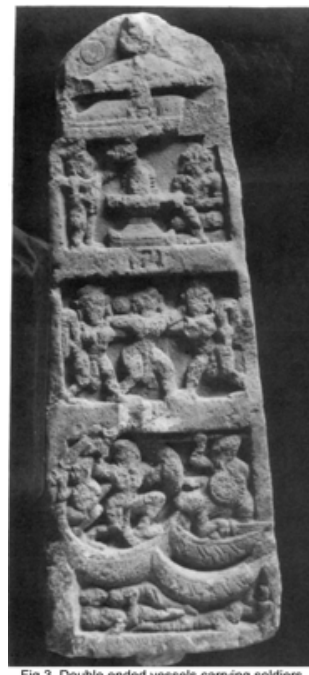

Fig. 3. Double ended vessels cartring soldiers Siva Linga and Moon, Old Goa Musue

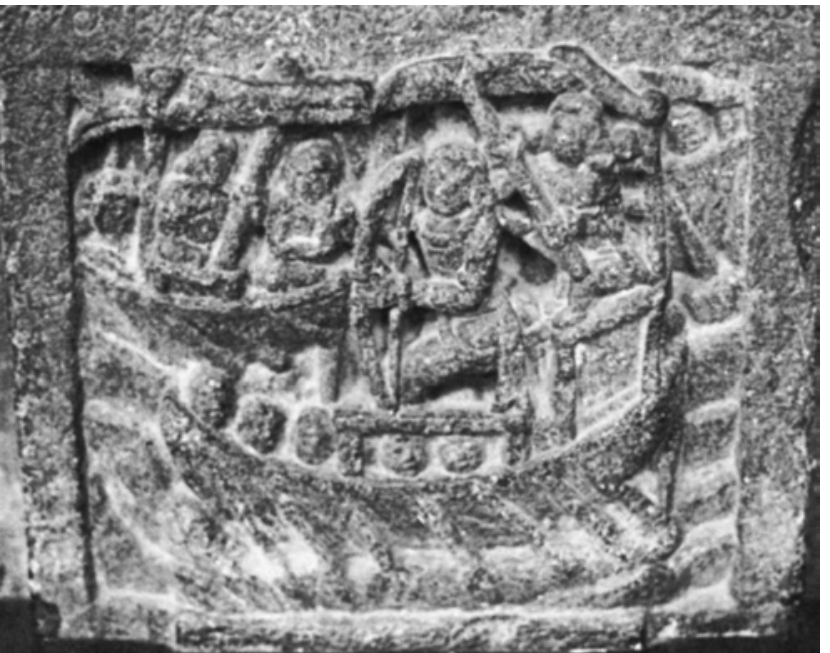

Fig. 4. A canoe shaped naval ship along with soldiers carrying bows, Old Goa Museum. Photo: Archaeological Survey of India.

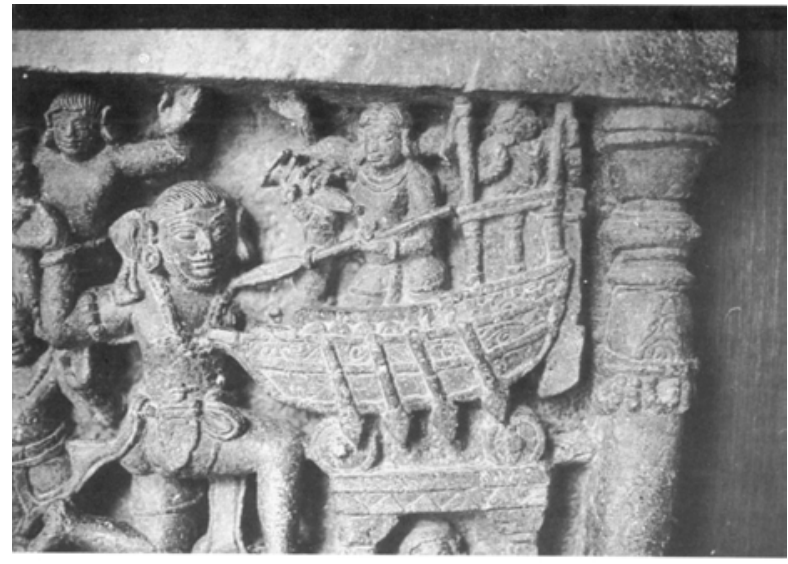

Fig. 5. Naval ship seen on roller, soldier holding spear, and fghting is going on,
Old Goa Museum. Photo: Archaeological Survey of India.

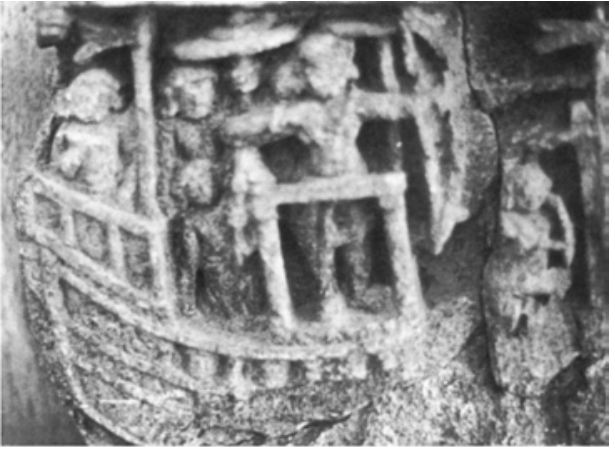

Fig.6. Naval ship carrying soldiers armed with bows, Old Goa Museum. Photo: Archaeological Survey of India 


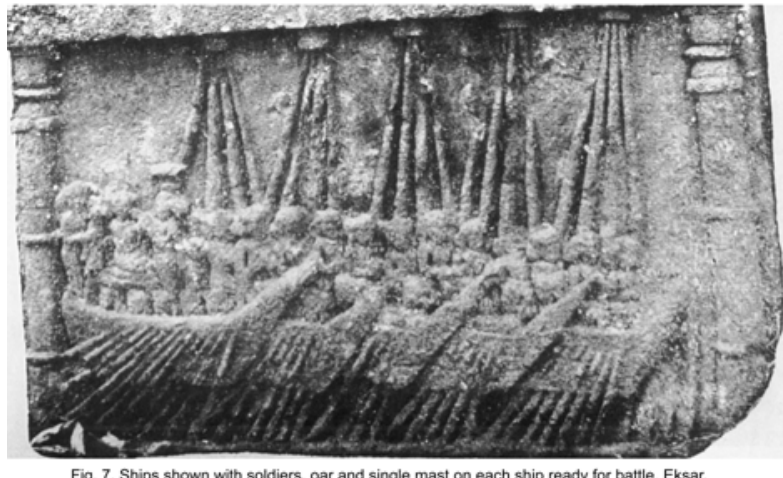

Fig. 7. Ships shown with soldiers, oar and single mast on each ship ready for battle, Eksar.
Photo: Archaeological Survey of India.


Fig.9. Ships proceeding from both sides for naval battle, Eksar. Photo: Archaeological Survey of India.

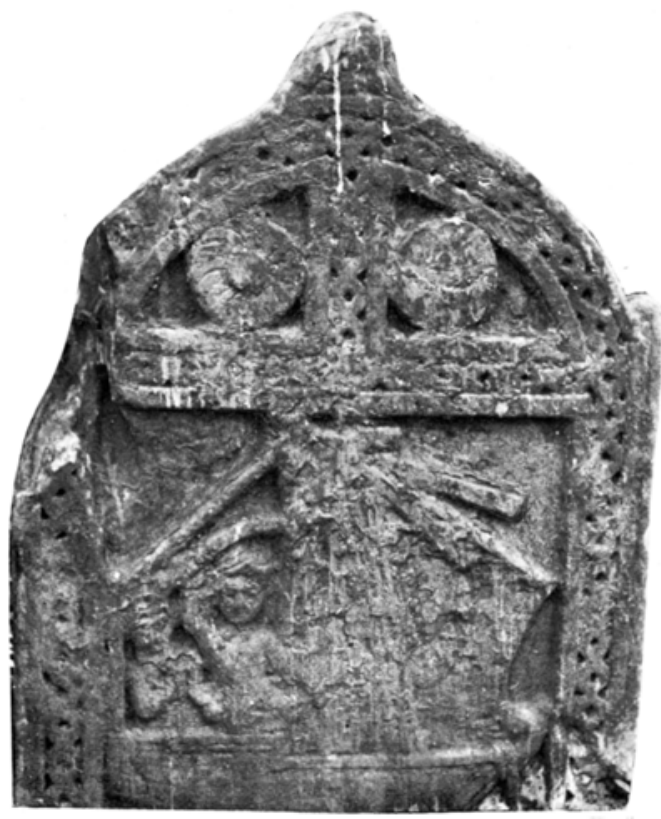

Fig.10. Hero stone shown with ship and sailors, (after Jain 1982).

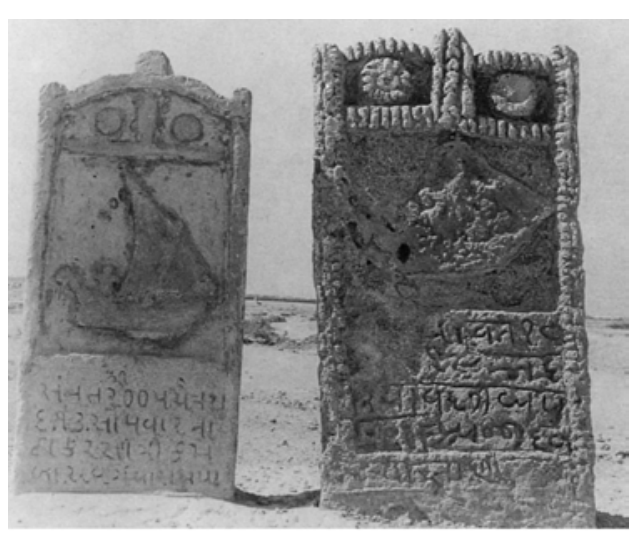

Fig.11. Two hero stones engraved with boat motifs and inscriptions, Aramda.

Photo: National Institute of Oceanography. 